\title{
HIGHER ORDER DYNAMIC INEQUALITIES ON TIME SCALES
}

\section{S. H. SAKER, R. P. AgArWAL AND DONAL O'REgAN}

Abstract. In this paper, we will prove some new dynamic inequalities of higher orders on time scales. The results contain some continuous and discrete inequalities as special cases. We will prove the results by making use of Hölder's inequality and Taylor monomials on time scales.

Mathematics subject classification (2010): 26A15, 26D10, 26D15, 39A13, 34A40. Keywords and phrases: Dynamic inequalities, higher order derivatives, time scales.

\section{REFERENCES}

[1] R. P. Agarwal, M. Bohner, Basic calculus on time scales and some of its applications, Results Math. 35 (1999), 3-22.

[2] R. P. Agarwal, M. Bohner, D. O'Regan and S. H. Saker, Some dynamic Wirtinger-type inequalities and their applications, Pacific J. Math. 252 (2011), 1-18.

[3] R. P. Agarwal and P. Y. H. PAng, Opial inequalities with Applications in Differential and Difference Equations, Kluwer, Dordrechet (1995).

[4] R. J. Higgins And A. Peterson, Cauchy functions and Taylor's formula for time scale $\mathbb{T}$, Proceeding of six Inter. Conf. Diff. Eqns., Roca Raton, FL, CRC. (2004), 299-308.

[5] M. Bohner And B. KaymakçAlan, Opial Inequalities on time scales, Ann. Polon. Math. 77, 1 (2001), 11-20.

[6] M. Bohner And A. Peterson, Dynamic Equations on Time Scales: An Introduction with Applications, Birkhäuser, Boston, 2001.

[7] M. Bohner And A. Peterson, Advances in Dynamic Equations on Time Scales, Birkhäuser, Boston, 2003.

[8] S. HILGER, Analysis on measure chains-a unified approach to continuous and discrete calculus, Results Math. 18 (1990), 18-56.

[9] V. KaC And P. Cheung, Quantum Calculus, Springer, New York, 2001.

[10] B. KARPUZ, B. KAYMAKÇALAN AND Ö. ÖCLAN, A generalization of Opial's inequality and applications to second order dynamic equations, Diff. Eqns. Dyn. Sys. 18 (2010), 11-18.

[11] W. G. Kelley And A. C. Peterson, Difference Equations; An Introduction with Applications, Academic Press, New York 1991.

[12] D. S. Mitinović, J. E. PeČArić And A. M. Fink, Classical and New Inequalties in Analysis, Kluwer Academic Publisher, 1993.

[13] C. OLECH, A simple proof of a certain result of Z.Opial, Ann. Polon. Math. 8 (1960), 61-63.

[14] Z. Opial, Sur uné inegalité, Ann. Polon. Math. 8 (1960), 92-32.

[15] S. H. SAKER, Applications of Wirtinger inequalities on the distribution of zeros of the Riemann Zetafunction, J. Ineq. Appl. 2010 (2010), 215416, 1-15.

[16] S. H. SAKER, Lyapunov inequalities for half-linear dynamic equations on time scales and disconjugacy, Dyn. Contin. Discr.Impuls. Syst. Series B: Applications \& Algorithms 18 (2011), 149-161.

[17] S. H. S AKER, Some Opial-type inequalities on time scales, Abstr. Appl. Anal. 2011 (2011), Article ID: 265316, 19 pages.

[18] S. H. SAKER, Applications of Opial and Wirtinger inequalities on zeros of third order differential equations, Dyn. Sys. Appl. 20 (2011), 479-494.

[19] S. H. SAKER, Lyapunov type inequalities for a second order differential equations with a damping term, Annales. Polon. Math. 103 (2012), 37-57. 
[20] S. H. SAKER, Opial's type inequalities on time scales and some applications, Annales Polon. Math. 104 (2012), 243-260.

[21] S. H. SAKER, New inequalities of Opial's type on time scales and some of their applications, Discrete Dynamics in Nature and Society 2012 (2012), Article ID 362526, 23 pages.

[22] H. M. Sirvastava, K. L. Tseng, S. J. Tseng And J. C. Lo, Some generalization of Maroni's inequality on time scales, Math. Ineq. Appl. 14 (2011), 469-480.

[23] H. M. Sirvastava, K. L. Tseng, S. J. Tseng And J. C. Lo, Some weighted Opial type inequalities on time scales, Taiwanese. J. Math. 14 (2010), 107-122.

[24] V. Spedding, Taming Nature's Numbers, New Scientist, July 19, 2003, 28-31.

[25] F. H. Wong, W. C. Lin, S. L. Yu And C. C. YeH, Some generalization of Opial's inequalities on time scales, Taiwanese. J. Math. 12 (2008), 463-471. 